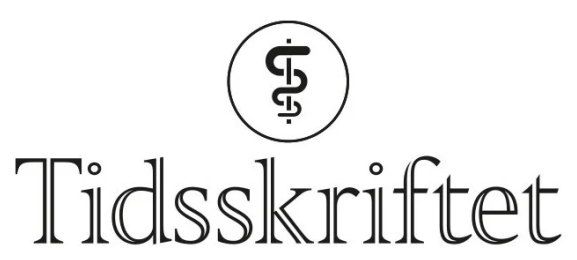

DEN NORSKE LEGEFORENING

\title{
Ingen lett utvei
}

\section{LEDER}

PREBEN AAVITSLAND

preben@epidemi.no

Preben Aavitsland er overlege ved Folkehelseinstituttet og kommuneoverlege i Arendal og Froland.

Forfatteren har fylt ut ICMJE-skjemaet og oppgir ingen interessekonflikter.

\section{Mens befolkningen prøver å finne en utvei til en normal hverdag, må vi begynne diskusjonen om hvordan vi skal leve med SARS-CoV-2 som et endemisk virus.}

Koronapandemien og tiltakene mot den har kostet mye i lidelse, død, penger og arbeidsplasser. Den direkte sykdomsbyrden er et produkt av hvor mange som blir smittet, og hvor alvorlig sykdom de får. Smitteverntiltakene har bidratt til at få i Norge er blitt smittet, og at de alvorlig syke har fått god behandling (1).

Vaksinasjon bidrar nå til at færre blir smittet, særlig blant dem med størst risiko, og at de vaksinerte som likevel blir smittet, får et mildere forløp. Vaksinasjon kan snart erstatte mange av de kontaktreduserende tiltakene. Andelen immune i befolkningen er nemlig like bestemmende for virusets spredningsevne som kontakthyppigheten i befolkningen, virusets smittsomhet og varigheten av den smittsomme perioden.

Pandemien har de siste 3-4 månedene delt landet i to (므). Det sentrale Østlandet i en bue fra Halden til Oslo og Nedre Romerike og deretter ned til Drammen har stått for minst to tredeler av alle tilfeller av infeksjon, sykdom og innleggelse (2). Her har det vært nødvendig med omfattende kontaktreduserende tiltak i flere måneder for å snu utviklingen og beskytte sykehusene mot overbelastning.

\section{«Norge går snart inn i overgangen fra en pandemi til en varig endemisk} situasjon»

Resten av landets kommuner har i hovedsak hatt få eller bare sporadiske tilfeller, men enkelte kommuner har opplevd utbrudd med noen titalls eller hundretalls tilfeller. Utbruddene er blitt stoppet i løpet av noen uker med testing, smitteoppsporing og karantene som hovedvirkemidler.

Veien ut av pandemien avhenger av at denne utviklingen fortsetter. Det krever for det første at mange flere får vaksinasjon som gir god og varig beskyttelse mot sykdom og videre smitte. Det er dette som er nøkkelen. For det andre må vi håpe at evolusjonen ikke 
frambringer nye virusvarianter som er enda mer smittsomme, som omgår tidligere immunitet eller som gir mer alvorlig sykdom. For det tredje må hardt pressede kommuner holde ut noen måneder til med koronavaksinasjon, testing og smitteoppsporing i tillegg til vanlig drift av sykehjem, legevakt, helsestasjon og mange andre helsetjenester. Til slutt må befolkningen i enda noen uker unngå nærkontakt med andre, særlig innendørs. Det blir krevende, særlig for de unge som vil nyte våren i selskap med andre, og som kanskje ikke lenger ser behovet for å beskytte den vaksinerte besteforeldregenerasjonen.

Norge går snart inn i overgangen fra en pandemi til en varig endemisk situasjon. Denne overgangsperioden, som trolig vil vare gjennom hele sommeren, blir utfordrende for mange. Kommunestyrer og regjering må vennes av med å forby reiser og normalt samkvem mellom innbyggerne. Helsemyndighetene må vennes av med å anbefale slike forbud uten skikkelige vurderinger av ulempene. Befolkningen må vennes til å leve uten kontaktreduserende tiltak, men med en liten risiko for å bli smittet. Forhåpentligvis blir pandemien så liten allerede i sommer at de uvaksinerte kan nyte de fleste friheter like mye som de vaksinerte, altså at utveien er åpen for alle.

\section{«Forhåpentligvis blir pandemien så liten allerede $i$ sommer at de uvaksinerte kan nyte de fleste friheter like mye som de vaksinerte»}

I denne perioden må vi starte diskusjonen om hva som skal være det nasjonale målet for årene framover med SARS-CoV-2. Skal målet være å fjerne viruset fra landet, å hindre ethvert utbrudd, å hindre enhver sykehusinnleggelse, å hindre ethvert dødsfall - eller noe annet? Og hvilke tiltak er akseptable for å nå målet (3)?

Forhåpentligvis vil vaksinasjon av mesteparten av den voksne befolkningen gjøre at covid19 i hovedsak blir en mild sykdom, fordi den nesten bare rammer voksne som har noe immunitet, og barn, som svært sjelden blir alvorlig syke av covid-19. Viruset vil spres dårligere jo større andel av befolkningen som er immun. Det vil derfor bli et spørsmål om også barn bør vaksineres for å øke andelen immune i befolkningen. Da må nytten veies opp mot de svært vanlige vaksinereaksjonene, som et par dager med smerter i armen, uvelhetsfølelse, feber, hodepine og muskel- og leddsmerter. Alternativet er at viruset sirkulerer blant barn, men også smitter vaksinerte voksne og dermed gir dem en oppfriskning av immuniteten.

Svekkes immuniteten naturlig etter vaksinasjon eller infeksjon, eller oppstår nye varianter som omgår tidligere immunitet, kan det bli nødvendig med ny vaksinasjon med en oppdatert vaksine. Det er uansett immuniteten som vil forandre SARS-CoV-2 fra et fryktet pandemisk virus til enda et endemisk koronavirus med liten sykdomsbyrde og risiko (4,.5).

\section{LITTERATUR}

1. Laake JH, Buanes EA, Småstuen MC et al. Characteristics, management and survival of ICU patients with coronavirus disease-19 in Norway, March-June 2020. A prospective observational study. Acta Anaesthesiol Scand 2021; 65: 618-28. [PubMed][CrossRef]

2. Covid-19. Ukerapport, uke 16. Oslo: Folkehelseinstituttet, 2021. https://www.fhi.no/contentassets/8a971e7boa3c4ao6bdbf381ab52e6157/vedlegg/2021/ukerapport-uke16-19.04---25.04.21.pdf Lest 29.4.2021.

3. Brean A. Hvor mange døde tåler vi? Tidsskr Nor Legeforen 2021; 141. doi:10.4045/tidsskr.21.04.01. [PubMed][CrossRef]

4. Kissler SM, Tedijanto C, Goldstein E et al. Projecting the transmission dynamics of SARS-CoV-2 through the postpandemic period. Science 2020;368: 860-8. [PubMed][CrossRef]

5. Lavine JS, Bjørnstad ON, Antia R. Immunological characteristics govern the transition of COVID-19 to endemicity. Science 2021; 371: 741-5. [PubMed][CrossRef] 
Publisert: 14. mai 2021. Tidsskr Nor Legeforen. DOI: 10.4045/tidsskr.21.0366

(C) Tidsskrift for Den norske legeforening 2023. Lastet ned fra tidsskriftet.no 26. april 2023. 